\title{
In vitro ANTIBACTERIAL ACTIVITIES OF GRAPE,Vitis vinifera, VINEGAR AGAINST Flavobacterium psychrophilum
}

\author{
Aysegül Kubilay $^{1 \S}$, Ahmet Duru ${ }^{1}$ \\ ${ }^{I}$ Department of Aquaculture, Faculty of Fisheries, SüleymanDemirel University, Isparta, TURKEY, \\ 32260
}

\begin{abstract}
The aim of this study was to assess the antibacterial activity of grape vinegar against $F$. psychrophilum. The antibacterial activity was determined by using agar well diffusion assays. The vinegar was tested against two strains of F.psychrophilum. While the highest inhibition zone diameter of grape vinegar was determined as $60 \mathrm{~mm}$, the lowest was $47 \mathrm{~mm}$ against to the pathogen. Grape vinegar displayed potent antibacterial activity against the tested two strains of bacteria with a diameter of inhibition zone ranging between $60 \mathrm{~mm}$ and $47 \mathrm{~mm}$. Antibacterial and immunostimulant properties of this vinegar is known to be therapeutic for human health in many diseases. The present study showed that it is also being found to be effective against fish pathogen. The results confirmed that the grape vinegar would be used as a potential source of antimicrobial agents in aquaculture for the control of infection which caused by Flavobacterium psychrophilum pathogen.
\end{abstract}

KEYWORDS: Grape vinegar, In vitro, bacteria, agar well diffusion, Flavobacterium psychrophilum.

${ }^{\S}$ Corresponding author. Tel.: +90 2462118666; Fax: +90 2462118697

E-mail address: aykub@yahoo.com 